\title{
ISLAMIC AGRICULTURAL ECONOMIC FINANCING BASED ON ZAKAT, INFAQ, ALMS AND WAQF IN EMPOWERING THE FARMING COMMUNITY
}

\author{
Muhammad Izzat Mohamed*, Muhammad Hakimi Mohd. Shafiai \\ Universiti Kebangsaan Malaysia (UKM), Selangor, Malaysia \\ muhammad.izzat.mohamed@gmail.com, hakimi@ukm.edu.my
}

https://doi.org/10.46367/iqtishaduna.v10i1.334

Received: Apr 30, 2021 Revised: Jun 21, 2021 Accepted: Jun 26, 2021 Published: Jun 29, 2021

\begin{abstract}
In the development of the agricultural sector, farmers are the key to its success. However, to a certain extent, specific interventions need to be done considering the problems faced by most farmers, such as financial constraints, lack of assistance, facilities, agricultural tools, and lack of land, which are obstacles to developing farmers enterprises. Therefore, this study attempts to analyze the potential of Islamic social finance tools in farmers development, particularly in facilitating financial problems of farmers in line with the government efforts in strengthening the agricultural sector. The distribution of productive zakat, infaq, alms and waqf (ZISWAF), based on the application of contractual contracts inherent from Islamic legislation and the management of productive ZISWAF, will be highlighted in this paper. The methodology of this study is based on a qualitative approach like gathering information from library research, and hence it is analyzed based on a deductive approach. The management of ZISWAF is divided into two, namely consumptive and productive ZISWAF. Consumptive ZISWAF can assist farmers in meeting their daily needs. At the same time, productive ZISWAF can develop farmers agricultural enterprises through musaqah, muzaraah, mukharabah, and ijarah contracts. Accordingly, it can be argued that Islamic social finance can play a positive role and be an alternative solution to farmers to promote agricultural land development.
\end{abstract}

Keywords: Productive ZISWAF, Mustahiq Farmers, Waqf Land.

\section{INTRODUCTION}

The development of the agricultural sector can be measured by looking at its farmers. The stronger the farmers' agricultural enterprise, the more it will contribute to the increase in agricultural production and attract the public to venture into this field. However, lack of finance, lack of assistance, facilities, agricultural and irrigation equipment, and lack of land can be obstacles for farmers to develop their agricultural enterprises for the better. 
This phenomenon is shown in a study conducted by Shafiai and Moi (2015) wherein his study; farmers have financial constraints in carrying out daily life and cultivating agricultural land. As many as 82 percent of the 138 respondents spend their agricultural produce in large quantities for their food from their farms, while only 25 respondents do not use their agricultural produce because they sell it to make it income. This shows that most farmers face financial constraints in terms of their daily consumption and for agricultural ventures. This indicates a negative cycle for agricultural development to develop further. Most studies look at Islamic banking or Islamic financing, which is a financial loan in nature in solving this problem which does not qualify mustahiq farmers to apply. In this study, looking at Islamic social finance as an alternative to this issue, namely zakat, infaq, alms, and waqf (ZISWAF). This writing is aware of the inability of farmers to repay loans so that this study will focus on the empowerment of mustahiq farmers compared to previous studies.

This study examines the potential of productive ZISWAF management through contracts in Islamic law to empower the mustahiq farming community that will contribute to the agricultural sector. The objective is to show ZISWAF is an alternative solution to the problems faced by farmers and is also one of the instruments that may activate and develop abandoned waqf land. There are two main scopes highlighted, namely, the first is the distribution of productive ZISWAF to overcome the financial constraints of mustahiq farmers without the burden of usury or loan repayment, and the second is the administration of ZISWAF property for the development of the agricultural sector.

Indeed, Islamic social finance is aimed at benefiting the mustahiq. Mustahiq, who get the productive ZISWAF fund, will use and grow them productively to improve their economy and produce something sustainably. Compared to conventional financing instruments, where mustahiq farmers do not want or are not eligible to use it to avoid the burden of interest payments and the nature of financing, which is more concerned with worldly profits.

\section{LITERATURE REVIEW}

\section{Zakat, Infaq, Alms, And Waqf (ZISWAF)}

Zakat is giving part of the property with certain conditions that Allah obligates the property owner to be handed over to those who are entitled to receive it according to sharia laws (Rasjid 1994). Zakat, which is closely related to agriculture, is agricultural zakat. The obligation to pay zakat consists of livestock stars, crops, and marine products that belong to the wealth from agriculture. Along with the word of Allah:

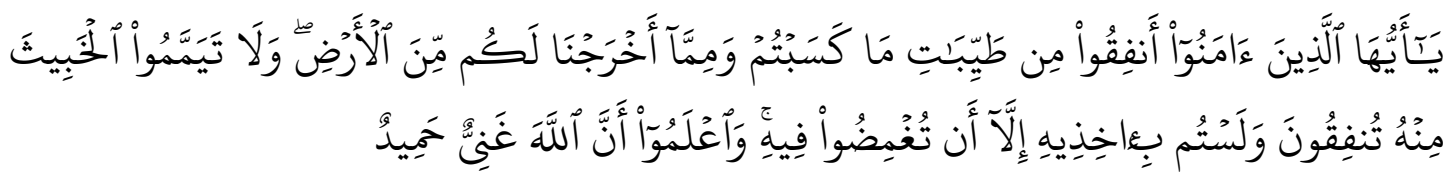

Meaning: "O you who have believed, spend from the good things which you have earned and from that which We have produced for you from the earth. And do not 
aim toward the defective therefrom; spending [from that] while you would not take it [yourself] except with closed eyes. And know that Allah is Free of need and Praiseworthy" (Q.S. Al-Baqarah: 267).

The word infaq means to donate property bestowed by Allah or to spend something on others to gain Allah's pleasure. It can be defined as a social practice of society and humanity in distributing part of the property to the needy (Arfawie 2005). The command to give infaq in the Qur'an is categorized into two categories, namely the obligatory infaq and nafl infaq. As Allah says:

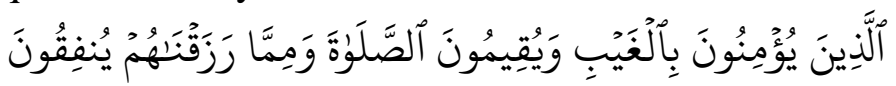

Meaning: "Who believe in the unseen, establish prayer, and spend out of what We have provided for them" (Q.S. Al-Baqarah: 3).

Some scholars assess the above verse, and it is obligatory infaq that is infaq from income or property that is not subject to the obligation of zakat. The most crucial obligatory infaq is the infaq of the husband to his wife, children and other dependents (nafkah).

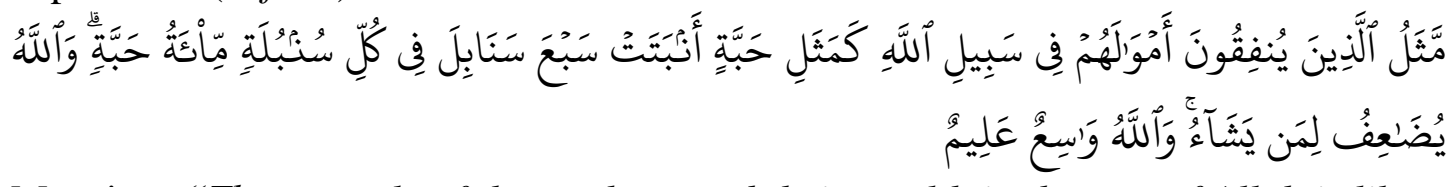

Meaning: "The example of those who spend their wealth in the way of Allah is like a seed [of grain] which grows seven spikes; in each spike is a hundred grains. And Allah multiplies [His reward] for whom He wills. And Allah is all-Encompassing and Knowings" (Q.S. Al-Baqarah: 261).

Nafl infaq when it has done, they will get reward and when left get nothing. However, the above verse is a parable given by Allah about the reward for those who spend their wealth by likening those who spend their wealth in the way of Allah like a farmer who plants seeds, this seed grows seven stalks, and each stalk produces a hundred seeds.

Alms are a gift of a religious Islam voluntarily without being limited haul and ratio as good in the hope of Allah's pleasure (Ruzian, Zakaria, and Halim 2015). According to Sabiq et al. (1990), that almsgiving is every charity done. So the meaning of alms is broader, including charity done through the giving of goods or non-goods. If compared to infaq, infaq includes the giving of property or goods while through one's actions such as a smile is also considered alms. The demand to give alms is one of the Islamic sharia. This is based on the words of Allah:

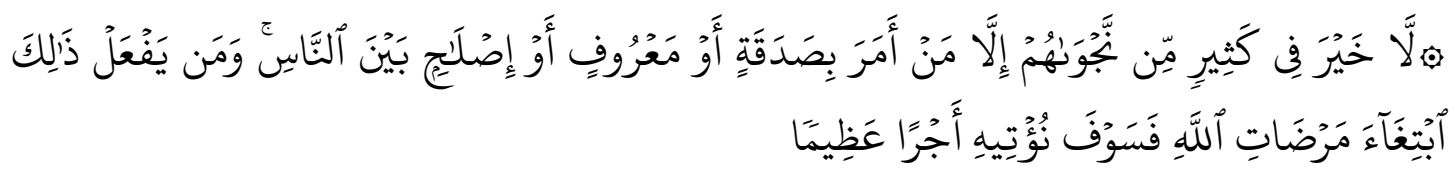

Meaning: "No good is there in much of their private conversation, except for those who enjoin almsgiving or that which is right or conciliation between people. And whoever does that seeking means to the approval of Allah, then We are going to give him a great reward" (Q.S. An-Nisa: 114).

Based on the sahih hadith of Al-Bukhari, Anas bin Malik RA once narrated that the Prophet Muhammad SAW said, which means: "There is none amongst the 
Muslims who plants a tree or sows seeds, and then a bird, or a person or an animal eats from it, but is regarded as a charitable gift for him". (Sahih al-Bukhari, number 2320). In agriculture, farmers who hope for the pleasure of Allah will be given an advantage where the reward will continue if the crops are utilized by other creatures and the income earned from crops is also blessed.

Waqf is the transfer of ownership of a property that has benefits and lasts to a person or nadzir (guardian of the waqf) so that the benefits of the property can be used towards religious, social interests (Rahman, Mansoer, and Muchtar 1986). Property that has been waqf is no longer the property of the person who waqf and does not belong to the waqf's guardian but belongs to Allah. In other words, that property belongs to the general public (Sudarsono 2012). The fundamental law of waqf is found in Quran, namely:

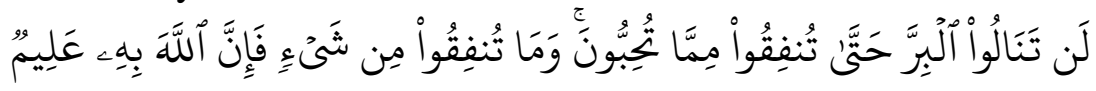

Meaning: "Never will you attain the good [reward] until you spend [in the way of Allah] from that which you love. And whatever you spend-indeed, Allah knows of it" (Q.S. Ali-Imram: 92).

Muslims are encouraged to waqf their property which they love for the benefit of the people. As long as the waqf property is utilized, the reward from Allah will continue to flow to the person who waqf even after death. In the agricultural sector, waqf is highly encouraged especially agricultural land. Transformation in the development of agricultural waqf can increase food security and can even be exported abroad if implemented systematically and planned.

The difference between zakat, infaq, alms, and waqf is: first, alms have more general meaning and alms are not subject to goods only to be done, where zakat, infaq, and waqf must be done by a specific method. Second, zakat has been determined the amount to be paid from the property owned, and when it needs to be implemented, in contrast to infaq, alms and waqf are not determined and can be implemented at any time. Third, zakat guides those who need to be given zakat and those who need to pay zakat, but infaq, alms can be given to anyone. Fourth, zakat is an obligation while waqf, infaq, and alms are encouraged sunnah practices (Uyun 2015).

\section{Economic Empowerment of Farmer's Communities}

This empowerment is to develop the community by supporting, motivating, and raising awareness of the potential and ability to develop for the better. So empowering the community means improving the economy of farmers to escape poverty and even increase food production from recent agricultural activities. Farmers are one of the keys for the agricultural sector to remain resilient (Firdaus et al. 2014). Abdullah and Arshad (2011) conducted a study that states that in paddy commodity agriculture, the government intervenes to help farmers and retain farmers to continue cultivating their paddy fields, thus enabling a competitive paddy production industry.

The study conducted by Mohammad et al. (2007); Kollurmath et al. (2010); Molua (2010); Tey et al. (2010) showed government assistance also to empower 
farmers through price control, subsidies, research, and development of fertilizers and technologies has a positive impact on food production and increases farmer's income. Farmers need technical support and access to better inputs such as finance, agrochemistry, better seed diversification, and technology to compete in the market. At the same time, governments and donors can also play a vital role (Harvey et al. 2018).

A study conducted by Alpízar et al. (2020) states that a concrete policy needs to be prepared and implemented for donors and policy implementers to address 32 percent of recurrent food insecurity in smallholder families. Policies should focus on farmer education, the guarantee of land ownership rights, empowerment of women farmers, knowledge to the new generation, and providing emergency food support in the season of natural disasters.

For the empowerment of ZISWAF funds, forms of distribution innovation are categorized into four forms (Mufraini 2006): (1) Traditional consumptive, ZISWAF is distributed to mustahiq for direct use. Example: zakat fitrah given to the poor to meet daily needs or zakat mal distributed to victims of natural disasters. (2) Creative consumptive, ZISWAF is created in another form from its original goods. Examples of school supplies or scholarships. (3) Traditional productive, ZISWAF is received in the form of productive goods such as goats, cows, etc. Giving in this form will be able to create a business that opens up jobs. (4) Creative productive, ZISWAF is created in the form of capital to develop social projects or increase the capital of small farmers.

These four mechanisms are fundamental to be implemented in community life to improve the standard of the social and economic life of the community as well as create a form of community that is faithful, peaceful, and harmonious. Public awareness needs to be increased to apply this system compared to the more popular conventional system nowadays. ZISWAF's fund management capabilities and more distribution to consumer-oriented also need to be taken into account (Mufraini 2006).

\section{ZISWAF Catalyst for Sustainable Farming Communities}

ZISWAF has an essential role concerning the empowerment of the agricultural economy where it has excellent benefits to the community and the country, primarily to ensure food security. According to Rofiq (2010), the distribution of ZISWAF funds needs to be distributed consumptively, but not all funds are spent consumptively. ZISWAF funds should also be distributed as an investment where it benefits the recipients to start efforts to improve the economy in the future.

According to Anwer (1995), the need to formulate short-term and long-term project planning for the community's economic development is less affordable. His study also showed that zakat and waqf have the potential to be invested for the long term, which has a positive effect on improving the less fortunate living standards. Kahf (1999) also made suggestions in his study to expand the benefits of zakat to eradicate poverty's root causes that stem from productivity and poor level of economic development. 
In the long term, the provision of productivity tools, capital provision, training, and employment can also be emphasized through ZISWAF to create or increase productivity while receiving ZISWAF funds consumptively (Suprayitno 2005). Therefore, zakat should be made a significant economic role to eradicate poverty (Kuran 2002).

A study was conducted in 2004 by the Islamic Development Bank (IsDB) in Jeddah, Saudi Arabia, to see if zakat funds were sufficient to meet the needs of the poor. In this study, 24 countries were represented to be the study sample. From this study, it was found that in countries with low per capita income, including high poverty, the amount of zakat collection is not enough to meet the needs of the poor. Therefore, efficiency and innovation in managing zakat funds need to be improved. The assistance given should not be in the form of income support or consumptively only. However, the assistance given in the form of productivity should also be given priority to increasing the productivity of the poor so that they can get out of poverty and become zakat payers (Ibrahim 2008).

In Indonesia, Dompet Dhuafa, as the largest Amil Zakat plan, uses ZISWAF funds in economic development programs instead of giving cash to the community. ZISWAF funds must be channeled through good entrepreneurship programs in agricultural economics, livestock, and marine fisheries. Programs can take the form of initial capital provision, skills, training, and guidance to create a business community and have the ability to access capital, minimize risk, manage the business and control economic assets.

According to Pailis, Burhan, and Ashar (2016), maqasid al-sharia, which includes several factors such as religious understanding, knowledge, and family concern, influence the recipients of productive zakat empowerment (mustahiq). The empowerment of mustahiq affects the well-being of individuals and society. Empowerment is meant through empowerment programs run by zakat managers (amil), mustahiq can receive assistance in the form of capital for business or investment. Deliberately, it will be useful and effective for the mustahiq who gets help and become a zakat payer.

Empirical studies show that the agricultural output or agricultural sector in Nigeria as a whole faces many problems which include inappropriate financing, low farm productivity, illiteracy of farmers, inadequate modern agricultural machinery and equipment, poor transportation and communication networks, among others (Anthony 2010; Awe 2013; Ogunbado and Ahmed 2015). Then in Kano, a Nigerian state, agricultural financing available through the conventional banking system is less desirable due to high-interest rates. The majority of Muslim farmers in that country are very reluctant and aware of non -adherence to religion. Then there was the decline in agricultural production. They suggested alternative agricultural activities that would benefit through an Islamic financial product called Salam financing (Mohammed, Ogunbado, and Aziz 2016).

According to Ahmed (2007), one of the essential aspects of waqf is that the idea of doing charity is not good. Possible waqf objectives for the community include providing religious services, socio-economic assistance to the needy, the poor, education, scholarship, and other purposes. However, it was found that waqf has been 
explicitly used for research in science, astronomy, and medicine. Similarly, there is also waqf of wheat to be used as seeds and a form of waqf to provide loans to people in need of funding.

As an economic explanation, for example, Jalil (2008) proposed that waqf contracts could be used to attract more public funds for the construction industry. Their proposal is based on the scenario of rising production costs and limited funding sources mainly to fund the development of several educational institutions such as universities and research centers. It can also be applied to the construction of agricultural structures. Then, Cizakca (1998) mentioned that the waqf system could provide the most critical social services at no cost to the government.

\section{Preserving Idle Agricultural Land}

First, idle land is a loss to the economy because it is a limited resource but not fully utilized. Second, there is a relationship between idle land and high poverty in rural areas. Third, the existence of idle land indicates that there are doubts about continuing to develop new lands. Furthermore, the land is idle because landowners are unable to cultivate their land. In addition, idle land also occurs because many people shift to the service and manufacturing sectors which offer higher average wages than engaging in agriculture (Vincent and Ali 2005).

Buang (2001) identified four main factors that cause abandoned agricultural land in Malaysia: (1) Poor physical properties, including climate, topography, soil type, water supply, and accessibility (soil factors). (2) Lack of technical knowledge (skills). (3) Economic constraints and social conditions such as uneconomic holding measures. (4) severe labor and machinery shortages, expensive inputs, uncertain market prospects and unequal competition from non-agricultural and urban sectors (economic), and negative attitudes and behaviors in farming communities, such as mistrust, discord, and lack of cooperation among landowners. Research conducted by Anem (2009) found that the factors contributing to idle land are small, scattered, uneconomical sized farms for crop development, lack of interest of farmers, no access and basic facilities, soil quality problems (peat soil), initially high development costs (over RM20,000/hectares), difficult to verify landowners and limited government assistance and subsidy programs.

Looking at the studies conducted by the researchers, it can be said that farmers need a system that can help them. Emphasis is also on a system that creates a narrowing income gap between rich and poor where the rich act as donors to distribute their wealth to the needy to improve their quality of life. Strengthening the agricultural economy means being able to develop the economic system of farming communities by increasing the community's ability as a whole and how to maximize and develop potential that can directly increase community productivity. Thus, the agricultural sector will be more sustainable, and food security is guaranteed from the individual to the country level. ZISWAF is a relevant system as a form of solution to humanitarian problems. ZISWAF is used consumptively and productively, which is useful for the recipients to generate added value in the economic chain. Therefore, it is necessary to study productive ZISWAF through contracts in Islamic law to 
empower mustahiq farming communities that will contribute to the agricultural sector.

\section{METHODS}

The design of the study is qualitative by absorbing the existing theories and analyzed descriptively. The design of this study allows for the construction of concepts and understandings needed to make assessments and provide recommendations concerning the problems studied. Data collection is from the library research method to obtain data and information related to issues and problems studied through the method of content analysis of secondary data from previous studies, related books, journals, and other references.

\section{RESULTS AND DISCUSSION}

ZISWAF is one of the primary economic resources for the Islamic State. The efficient and systematic management of ZISWAF can boost the potential of ZISWAF as an instrument for the development of the farming community. Optimizing the benefits of ZISWAF funds should be essential to improve the quality and potential of each farmer. In Malaysia, the administration and management of zakat are managed by the Majlis Agama Islam Negeri (MAIN). MAIN is responsible for determining the eligibility of recipients and the form of assistance that is appropriate to the background of each recipient so that the assistance provided can be utilized as much as possible.

\section{Optimizing the Potential of ZISWAF}

In general, the results of ZISWAF collected for zakat recipients are done based on the following requirements: Eight asnaf, people who are more in need, and their respective regions. The provision of ZISWAF to farmers can develop the economy of farmers and directly to food security. However, the question is whether the provision of ZISWAF without any development planning can develop the economy of the farming community. At the same time, ZISWAF aims to eradicate poverty with the hope of improving the economy of zakat recipients to become zakat payers so that the use of ZISWAF funds becomes more meaningful and more functional.

The productive division of ZISWAF needs to be scrutinized and considered in a balanced manner with consumptive ZISWAF and carried out systematically. Consumptive distribution of ZISWAF is still needed, but not all ZISWAF funds that have been collected have been spent. ZISWAF funds can also be categorized into investment by giving or injecting capital to mustahiq to be better able to improve their enterprises and economy. The return from ZISWAF's investment is more in social improvement, which is to eradicate poverty and create a developing socioeconomy compared to the return of financial profits. However, the productive categorization of ZISWAF requires careful procedures for its systematic and 
functional management. The priority is to build a profile where this profile aims to identify the status of qualifications, including expertise or companies that ZISWAF recipients are developing.

The management of ZISWAF funds needs to be managed in two ways to optimize its management potential. The first way, ZISWAF funds will be distributed for consumptive use to meet the economic policy needs of the needy such as food, shelter, education, and various other necessities of life. The second way, ZISWAF funds will be distributed productively; that is, it can be created through assistance programs for weak enterprises in equipment or finance and will be set targets for mustahiq economic achievement in return for productive investment ZISWAF funds.

\section{Productive ZISWAF Management}

The poor who can work are still young and do not have disabilities; it is recommended that they be given capital or training to ensure that they productively receive zakat assistance and not just money alone. The management of zakat in Islam is an activity that has been in the Islamic guide and is already practiced by the Prophet SAW and then the companions. This model of zakat productive management has been described in the time of Caliph Umar Ibn Khathab who gave zakat in the form of three camels at once to one of the mustahiq who always asked for his zakat but his fate had not changed. At the time of handing over the three camels, the caliph hoped that his situation would change into a zakat payer. Hope Caliph Umar Ibn Khathab is true, wherein the next years this man came to the Caliph Umar Ibn Khathab not asking for zakat, but to give up their zakat.

Productive ZISWAF management required four management functions which include planning, organizing, action, and oversight. Productive ZISWAF management has the concept of careful planning and implementation, such as studying the causes of poverty, lack of working capital, and lack of employment. With the data, then there needs to be planning that can develop the productive zakat. This productive distribution of ZISWAF is given to individuals who can generate benefits in the long run and release the economic dependence of the poor from the help of others. Recipients of this productive ZISWAF must meet three conditions: the first; already has a qualified, productive effort or expertise in farming. Second, be willing to accept a companion who serves as a mentor, and third, is willing to submit periodic effort reports (Yusuf 2015). Productive ZISWAF is a model of zakat distribution that can build the economy of the mustahiqs to be stable. By encouraging the mustahiqs to generate income on something continuously with ZISWAF property obtained, it will not be spent and continuously developed to meet their daily lives (Toriquddin 2015).

Based on Figure 1 shown, ZISWAF's fund management effort consists of two activities, namely collection and distribution. In ZISWAF, fund collection can be done in fundraising, which includes meeting zakat payers in person, social media, organizing the gathering in the form of campaigns, online banking and so on. ZISWAF fund distribution activities are carried out or done in the form of productive programs such as education scholarships, training and coaching, facilities and 
infrastructure, and productive capital in line with forms of consumptive distribution programs such as distribution of groceries or cash.

Figure 1 ZISWAF Management Model

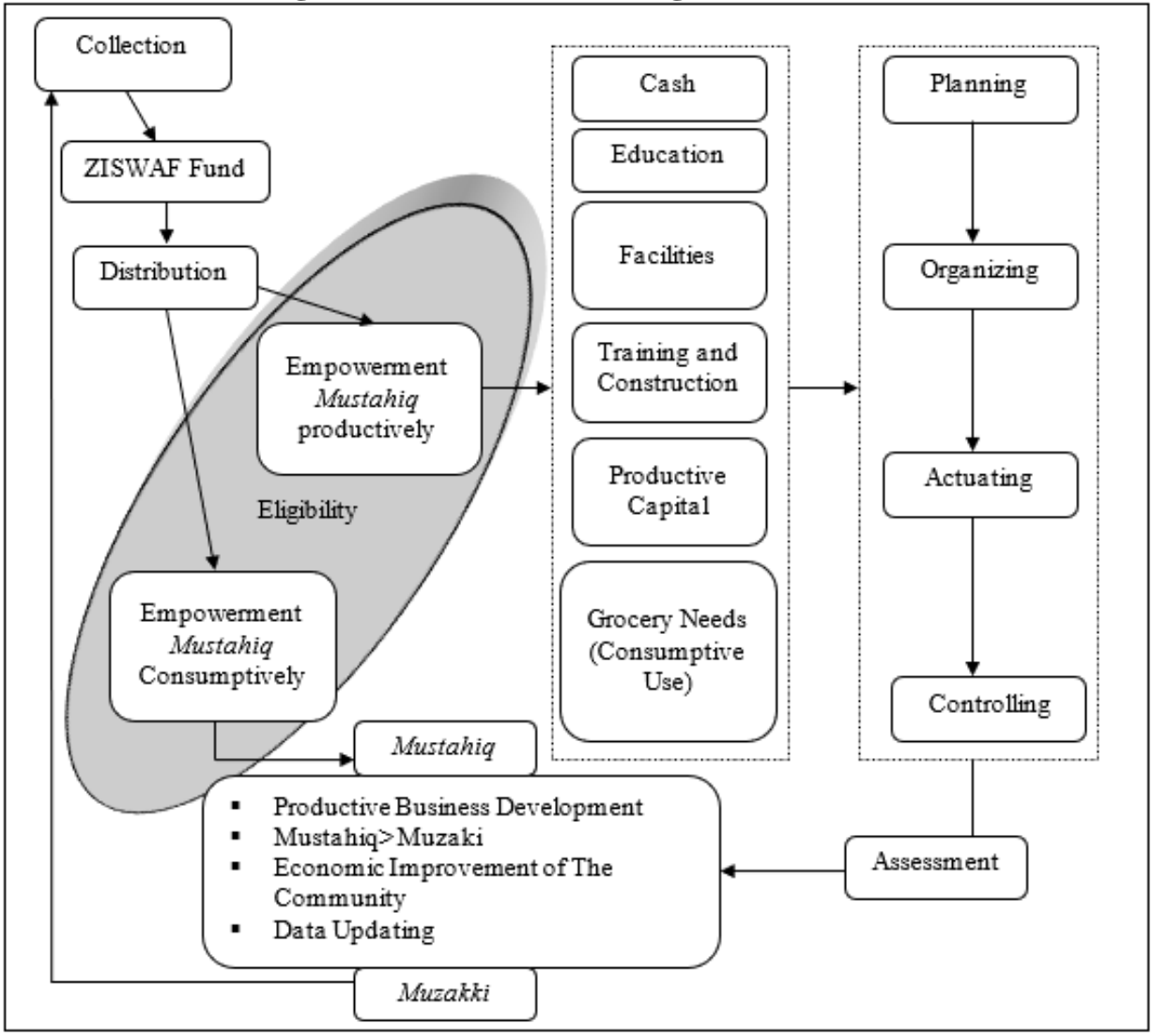

Source: processed data

\section{Productive ZISWAF Management Methods}

In the planning process, plan a comprehensive action that will be implemented to achieve a productive assistance program. In the early stages of providing venture capital to farmers, it is necessary to conduct field surveys and socialize the program with recipients to equate the views and understanding of the program.

Next is in the organizing process; data collection should be done on all available mustahiq. Then the productive ZISWAF assets that can be used or are fit to be used follow the productive assistance program. ZISWAF collection from waqf givers or zakat payers also participates in productive assistance programs. Then from the data collection will form a proposal to the zakat agency to organize appropriately as a consideration for the mustahiq that needs to be courtesy with productive ZISWAF funds in line with its expertise in agriculture.

In the actuating process, the description of the tasks establishes a contract of agreement between the waqf giver, the zakat agency, and the productive ZISWAF recipient who has been selected. Data collection of productive ZISWAF recipients will be done by including the conditions agreed upon, such as duration, type of 
assistance, revenue distribution and benefit distribution to the community, etc. In this process, there will be the distribution of capital, the distribution of agricultural tools, or land preparation for productive endeavors.

Finally, the controlling process, the monitoring activities carried out continuously by the zakat agency to find out the progress of the efforts made by the mustahiq. Mustahiq will provide periodic reports on the development of the enterprise, and the zakat agency must also go down to the field for survey activities to make assess to avoid waste and failure. The monitoring and evaluation process should cover the development of the business, the problems encountered, and identify indicators of success until there is a change of status from mustahiq to muzakki.

\section{The Basic Framework of Agricultural Product and ZISWAF}

In this research, look at the form of productive ZISWAF management recommended by previous Islamic scholars, namely the four schemes shown in Figure 2. The first scheme is land, agricultural tools, plant seeds, and livestock provided by the zakat agency while farmers carry out agricultural activities (efforts). Zakat agencies will provide funds for an agricultural start-up in the immediate context, while farmers provide labor. Thus, in this context, the scheme can be used to obtain seeds, fertilizers, pesticides, irrigation, storage, and marketing requirements of agricultural commodities. The zakat agency can use the waqf land and then give it to potential farmers to cultivate it according to the productive method. In this case, the zakat agency holds the trust as the custodian of the waqf land and has cooperation with the farmers.

The second scheme is land provided by the zakat agency, and the rest is provided by farmers different from the first scheme. In the second scheme, farmers provide agricultural tools, plant seeds, livestock farming, and then do agricultural activities. In this context, farmers have the equipment to carry out agricultural activities but do not have or cannot afford to rent land for cultivation. The third scheme is that the zakat agency assists in agricultural tools, plant seeds, and livestock while farmers have land and engage in agricultural activities. Moreover, in the fourth scheme, the zakat agency only assists in the equipment of agricultural tools while the farmers already have land, plant seeds, and livestock and do agricultural activities.

Agricultural tools, plant seeds, and livestock are productive assistance that can be given directly, which aims to help increase the efficiency and improvement of agricultural activities to a better level. For assistance in terms of land will involve high and limited costs. In this way, waqf property can be used to have economic value and be a productive waqf. According to Kahf (2003), waqf property has economic value when used productively.

In terms of its object, the productive waqf is divided into two, namely productive waqf in money and productive waqf for immovable property. Thus the land is included in the productive waqf for immovable property (Mifedwil 2008). Productive waqf management for agricultural land will involve contracts in developing waqf property while improving the economic ability of farmers based on the scope and principles that exist in the Islamic waqf law so that there is no wastage 
of waqf property and failure of farmers. Among the contract that can be applied is musaqah, muzaraah, mukhabarah, and ijarah.

Figure 2 The Basic Framework of Agricultural Product and ZISWAF

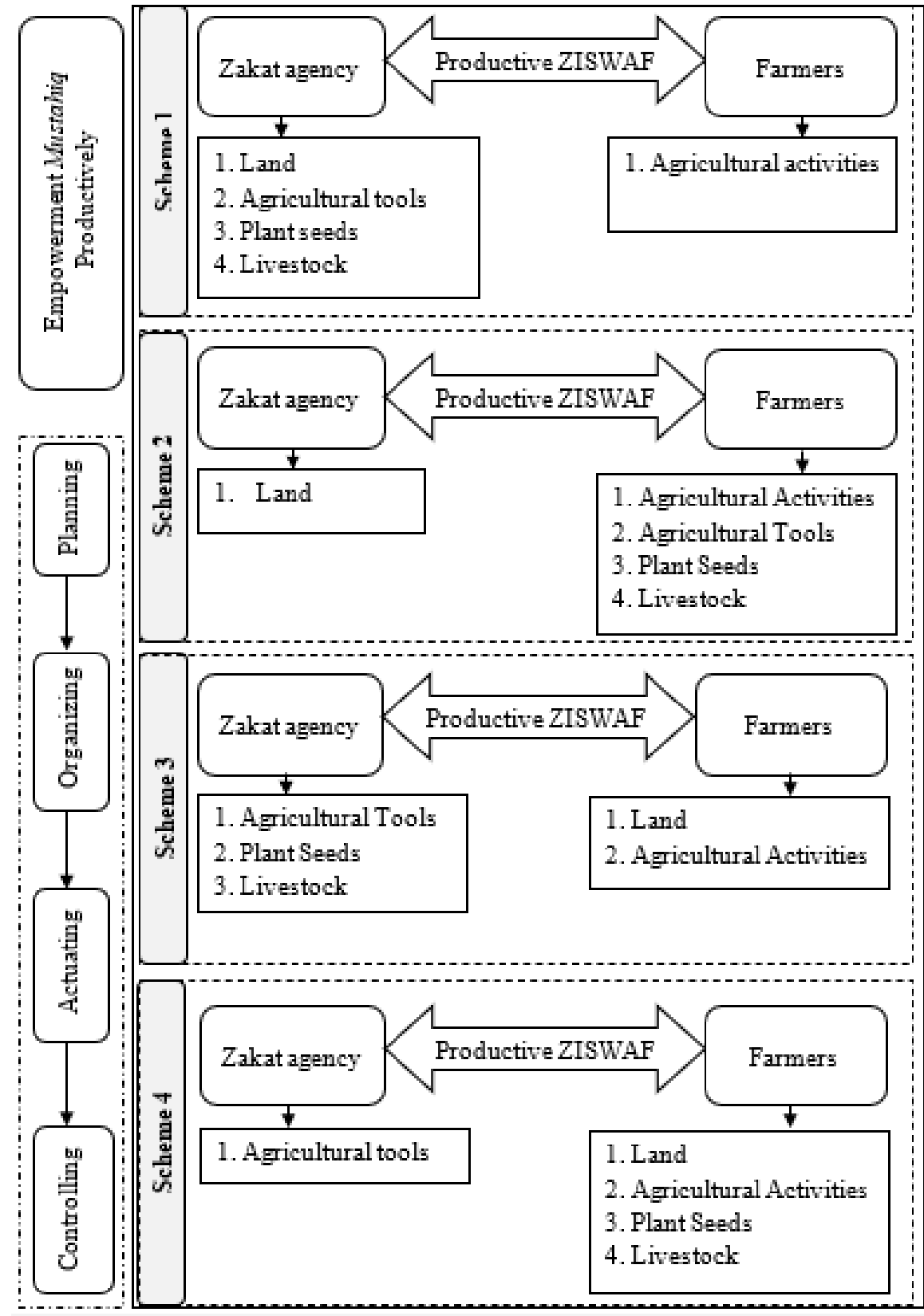

Source: processed data from Shafiai and Moi (2015).

\section{Musaqah Contract}

Hamid (2012) defines musaqah as a transaction to hand over a tree that has not been valued, to be watered and treated until the fruit is ripe, with a payment taken from that part of the fruit. According to most scholars, the five pillars of musaqah 
(Az-Zuhaili 1999), namely: both parties to the contract, the source of work/object of musaqah, fruit, work, ijab and qabul.

Figure 3 Operating Module of Musaqah

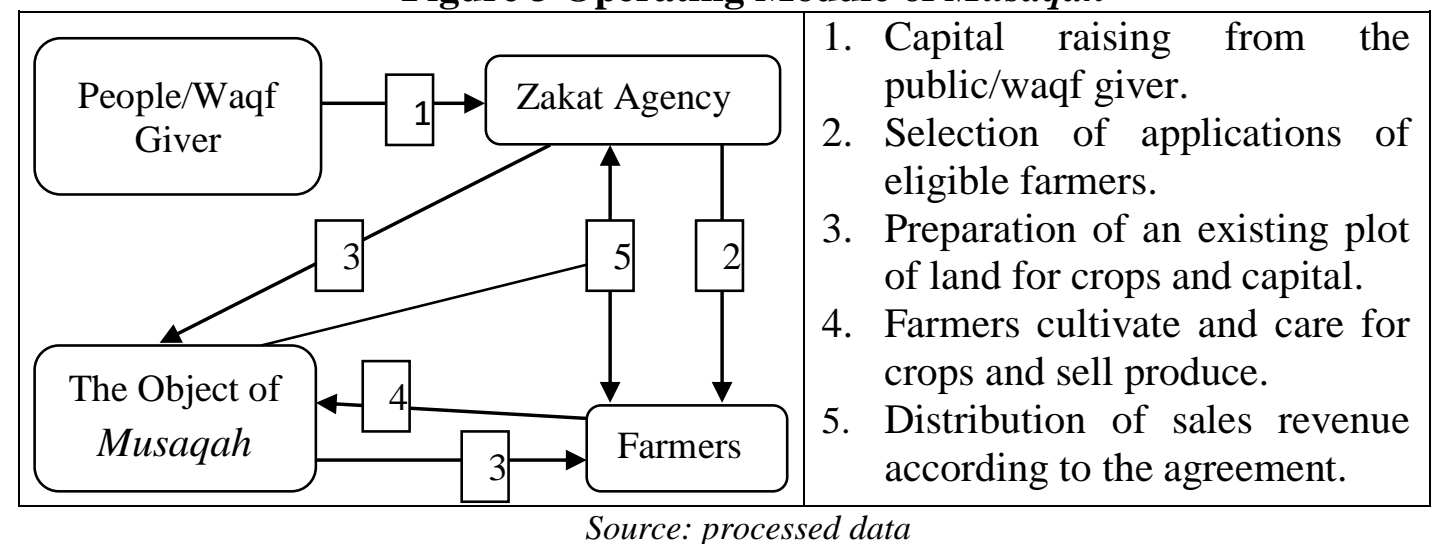

\section{Muzaraah Contract}

According to Al-Qaradhawi (2016), muzaraah is the landowner handing over tools, seeds, and animals to those who want to plant them with a condition he will get the result that has been determined; $1 / 2,1 / 3$ or less or more by mutual agreement. The jurists determine the important elements that participate in the contract of muzaraah, which are as follows (Az-Zuhaili 1999): landowners, farmers, the object of muzaraah, ijab and qabul.

Figure 4 Operating Module of Muzaraah

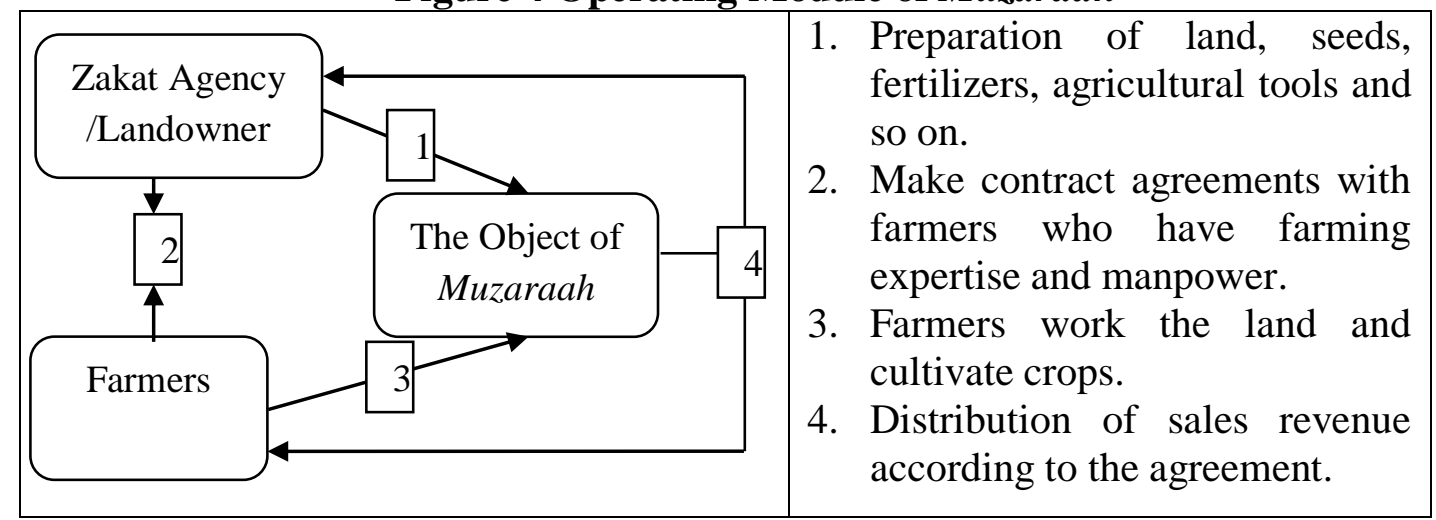

Source: processed data

\section{Mukhabarah Contract}

According to Rasjid (1994), mukhabarah is a landowner who hands over land and is worked by farmers such as paddy fields or crop fields in return for a portion of the produce $(1 / 2,1 / 3$, or $1 / 4)$ where the cultivating farmer bears tools, seeds, and animals. The majority of scholars who allow the contract of mukhabarah presents the pillars that must be covered. The contract is considered valid as follows (Az-Zuhaili 1999): landowners, farmers, the object of mukhabarah, ijab and qabul. 


\section{Figure 5 Operating Module of Mukharabah}

Zakat Agency
Fandowner

Source: processed data

\section{Ijarah Contract}

Al-Kasani (1998) defines ijarah as rent or wages as a contract of sale and purchase on benefits with replacement payment. Payment of wages or rent is in place of benefits received. This means that agricultural land will be leased to farmers to use its benefits, and farmers will pay rent in return. According to the majority of scholars, there are four pillars of ijarah (Az-Zuhaili 1999), namely: landlords and tenants, ijab and qabul, object of ijarah (benefits), ujrah (wages or rent).

\section{Figure 6 Operating Module of Ijarah}

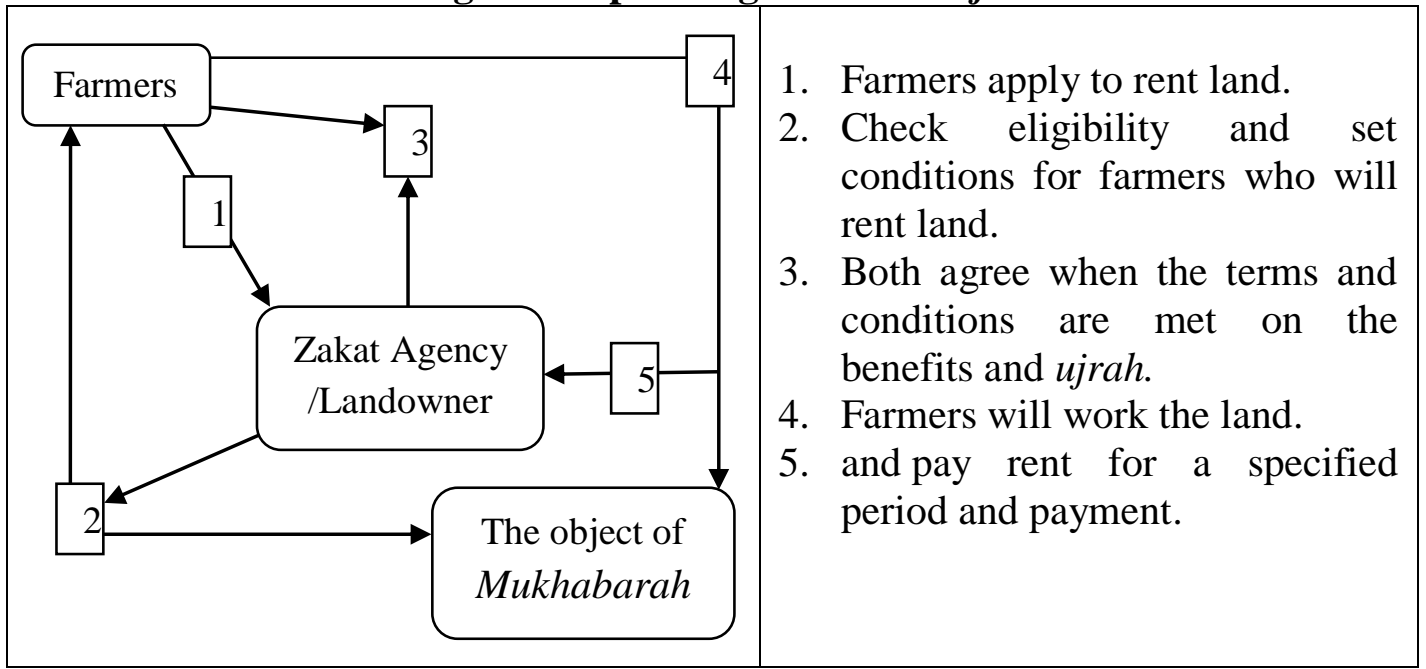

Source: processed data 


\section{CONCLUSION}

Islamic economic agriculture can be developed through the management of ZISWAF distribution consumptively and productively. The main results of the research show that the distribution of consumptive ZISWAF can help mustahiq farmers to meet their needs. However, to develop the economy of mustahiq farmers, the distribution of productive ZISWAF should also be given emphasis. Productive ZISWAF management can be done by applying sharia contracts namely musaqah, muzaraah, mukharabah and ijarah. The research results also show that the application of these contracts can take care of ZISWAF properties such as lands, buildings, gardens, etc.

Through the perfect and systematic distribution of ZISWAF, the agricultural economy of Muslims can be generated to a higher level through enterprise cooperation programs and assistance following contracts guided by Islam. This will produce a linked effect where the economic growth of the mustahiq farming community is getting better, creating a robust and resilient agricultural sector, and the social welfare system will strengthen the relationship between the rich and the poor. The increase in the economy has a significant impact on the increase in ZISWAF funds.

Therefore, this effort requires careful planning through human resources and structured strategies through a solid organizational body. Thus, the administration of ZISWAF through social institutions needs to be developed and enhanced through sustainable and intact management so that institutions that manage ZISWAF assets can build a new dimension by collaborating with other institutions, especially in the agricultural sector, to become competitive institutions and able to play an effective role at the local, regional and global levels. For further studies, the study needs to be done by looking at fields such as the mustahiq farmer community questionnaire and the network of ZISWAF institutions and agricultural sector institutions, the extent of cooperation that exists to drive the Islamic economic development program.

\section{REFERENCES}

Abdullah, Mahir, and Fatimah Mohamed Arshad. 2011. Kajian Impak Skim Subsidi Baja Padi Kerajaan Persekutuan (SSBPKP) dan Skim Subsidi Harga Padi (SSHP). The final report of the study submitted to the Ministry of Agriculture and Agro-base Industry Malaysia.

Ahmed, Habib. 2007. "Waqf-Based Microfinance: Realizing The Social Role of Islamic Finance". International Seminar on Integrating Awqaf in the Islamic Financial Sector Singapore, 1-22. https://www.findevgateway.org/sites/default/files/publications/files/mfg-enpaper-waqf-based-microfinance-realizing-the-social-role-of-islamic-finance2007.pdf. 
Al-Kasani, Alaudin Abu Bakar bin Mas'ud. 1998. Bada"i" Al-Sana"i", Jilid. 5. Lubnan: Dar Ihya al_Turath al-Arabi.

Alpízar, Francisco, Milagro Saborío-Rodríguez, M. Ruth Martínez-Rodríguez, Bárbara Viguera, Raffaele Vignola, Tabaré Capitán, and Celia A. Harvey. 2020. "Determinants of Food Insecurity among Smallholder Farmer Households in Central America: Recurrent versus Extreme Weather-Driven Events." Regional Environmental Change 20, 22. https://doi.org/10.1007/s10113-020-01592-y.

Al-Qaradhawi, Yusuf. and Mohd Hafiz bin Daud. 2016. Halal dan haram dalam Islam. PTS Publishing House Sdn. Bhd.

Anem, Mohd. 2009. Idle Land - Development Project. Anim Agro Technology. Accessed from http://animhosnan.blogspot.com/2009/10/development-of-idleland.html, 15 January 2021.

Anthony, David W. 2010. The Horse, The Wheel, And Language: How Bronze-Age Riders From The Eurasian Steppes Shaped The Modern World. Princeton University Press.

Anwer, Muhammad. 1995. "Financial Socio-Economic Development With Zakah Funds". Journal of Islamic Economics 4 (1), 15-32.

Arfawie, Nukthoh Kurde. 2005. Memungut Zakat \& Infaq Profesi Oleh Pemerintah Daerah (Bagi Pegawai Negeri Dan Pegawai Perusahaan Daerah). Yogyakarta: Pustaka Pelajar.

Awe, A. A. 2013. "Government Expenditure and Poverty Reduction in Ekiti State, Nigeria". Research Journal of Finance and Accounting 4 (5), 95-104.

Az-Zuhaili, Wahbah. 1999. Fiqh Perundangan Islam, terj. Dr. Ahmad Shahbari Salamon et.al, Jilid V. Kuala Lumpur: Dewan Bahasa dan Pustaka.

Buang, Amriah. 2001. "Privatizing The Rehabilitation Of Idle Agriculture Land In Malaysia Feedback From The Malay Folks". Pertanika Journal of Social $\begin{array}{llll}\text { Sciences } \quad \text { \& } & \text { Humanities } 9 & \text { (2). }\end{array}$ http://psasir.upm.edu.my/id/eprint/57702/1/JSSH\%20Vol.\%209\%20\%282\%2 9\%20Sep.\%202001\%20\%28View\%20Full\%20Journal\%29.pdf\#page=33.

Cizakca, Murat. 1998. "Awqaf in History and Its Implications for Modern Islamic Economies". Islamic Economic $\quad$ Studies $6 \quad$ (1), $43-70$. https://ssrn.com/abstract=3164811.

Firdaus, R. B. Radin, Ahmad Zubir Ibrahim, Chamhuri Siwar, and Abdul Hamid Jaafar. 2014. "Penghidupan Petani Padi Dalam Mendepani Cabaran Perubahan Iklim: Peranan Intervensi Kerajaan Menerusi Skim Subsidi Harga Padi (SSHP)". Kajian Malaysia $32 \quad$ (2), 73-92. http://web.usm.my/km/32(2)2014/KM\%2032(2)\%202014\%20$\% 20$ Art.\%204.pdf.

Hamid, Husein Abdul. 2012. Mukhtasar Kitab al-Umm fi al-Fiqh Imam al-Syafi'i, Translate by: M. Mujib et.al. Johor Bahru: Perniagaan Jahabersa.

Harvey, Celia A., Milagro Saborio-Rodríguez, M. Ruth Martinez-Rodríguez, Barbara Viguera, Adina Chain-Guadarrama, Raffaele Vignola, and Francisco Alpizar. 2018. "Climate Change Impacts and Adaptation among Smallholder Farmers 
in Central America". Agriculture and Food Security 7, 1-20. https://doi.org/10.1186/s40066-018-0209-x.

Ibrahim, Patmawati. 2008. "Pembangunan Ekonomi Melalui Agihan Zakat: Tinjauan Empirikal”. Jurnal Syariah $16 \quad$ (2), 1-23. https://ejournal.um.edu.my/index.php/JS/article/view/22763.

Jalil, Abdullaah. 2008. "Waqf Instruments for Construction Contract: An Analysis of Structure. The Journal of Muamalat and Islamic Finance Research (JMIFR) 5 (1), 1-13. https://ssrn.com/abstract=1799084.

Kahf, Monzer. 1999. "The Performance of the Institution of Zakah in Theory and Practice." International Conference on Islamic Economics Towards the 21st Century, Kuala Lumpur, $1-40$. http://ierc.sbu.ac.ir/File/Article/the\%20performance\%20of\%20the\%20institut on\%20of\%20zakah\%20in\%20theory\%20and\%20practice_94689.pdf.

Kahf, Monzer. 2003. "The Role of Waqf in Improving The Ummah Welfare". International Seminar on Waqf as a Private Legal Body, Medan, Indonesia, 67.

http://eprc.sbu.ac.ir/File/Article/the\%20role\%20of\%20waqf\%20in\%20improv ing\%20the\%20ummah\%20welfar_94755.pdf.

Kollurmath, Vijayakumar B., N. N. Karnool, L.B. Kunnal, H. Basavaraj, and Vilas Kulkarni. 2010. "Supply Response of Rice and Maize in Karnataka Pre and Post WTO". Karnataka Journal of Agricultural Sciences 21 (4).

Kuran, Timur. 2002. "Islamic Redistribution Through Zakat: Medieval Roots of Contemporary Problems". Conference on Poverty and Charity in the Forthcoming in Conference Volume, Suny Press. Middle East, 21-22.

Mifedwil, Jandra. 2008. "Memproduktifkan Wakaf: Pengalaman di Indonesia". Prosiding Konvensyen Kebangsaan Pengurusan Harta Pusaka, Wasiat \& Wakaf Universiti Kebangsaan Malaysia 24, 419-452.

Mufraini, M. Arief. 2006. Akuntansi dan Manajemen Zakat: Mengomunikasikan Kesadaran dan Membangun Jaringan. Jakarta: Kencana Prenada Media Group.

Mohammad, Shafique, Muhammad Siddique Javed, Bashir Ahmad, and Khalid Mushtaq. 2007. "Price and Non-Price Factors Affecting Acreage Response of Wheat in Different Agro-Ecological Zones in Punjab: A Co-Integration Analysis" 44 (2): 370-77. https://www.pakjas.com.pk/papers/343.pdf.

Mohammed, Ahmed Ibrahim, Ahamad Faosiy Ogunbado, and Ahmad Bashir Aziz. 2016. "The Viability of Salam Finance in the Growth of Agricultural Production in Kano State, Nigeria". Asian Journal of Multidisciplinary Studies 4 (12), 87-92. http://repo.uum.edu.my/21893/.

Molua, L. Ernest. 2010. "Response of Rice Yields in Cameroon: Some Implications for Agricultural Price Policy". Libyan Agriculture Research Center Journal International 1 (3), 182-194. https://www.researchgate.net/profile/ErnestMolua/publication/266090183_Response_of_Rice_Yields_in_Cameroon_So me_Implications_for_Agricultural_Price_Policy/links/55277d960cf229e6d63 6194c/Response-of-Rice-Yields-in-Cameroon-Some-Implications-forAgricultural-Price-Policy.pdf. 
Ogunbado, Ahamad Faosiy, and Umar Ahmed. 2015. "Bay' Salam as an Islamic Financial Alternative for Agricultural Sustainability in Nigeria". Journal of Islamic Economics Banking and Finance 11 (4), 63-75. https://doi.org/10.12816/0024789.

Pailis, E. Armas, Umar Burhan, and K. Ashar. 2016. "The Influence of Maqashid syariah toward Mustahik's Empowerment and Welfare (Study of Productive Zakat Recipients on Baznas Riau)". American Journal of Economics 6 (2), 96106.

Rahman, Asymuni A., Tolchah Mansoer, and Kamal Muchtar. 1986. Ilmu Fiqih 3. Jakarta: Proyek Pembinaan Prasarana \& Sarana Perguruan Tinggi Agama Islam.

Rasjid, Sulaiman. 1994. Fiqih Islam. Bandung: Sinar Baru Algensindo.

Rofiq, Ahmad. 2010. Kompilasi Zakat. Semarang: Balai Penelitian Dan Pengembangan Agama.

Ruzian Markom, Mohammad Ramzi Zakaria and Asma Hakimah Ab. Halim. 2015. "Kerangka Perundangan Rumah Sedekah sebagai Institusi Perbankan: Satu Tinjauan Awal". 1st Seminar on Sadaqa House, 23-31.

Sabiq, As-Sayyid, Nor Hasanuddin, Aisyah Saipuddin, and Johari al-Yamani. 1990. Fiqh al-sunnah. Dār al-Rayān lil-Turāth.

Shafiai, Muhammad Hakimi Mohd., and Mohammed Rizki Moi. 2015. "Financial Problems among Farmers in Malaysia: Islamic Agricultural Finance as a Possible Solution". Asian Social Science 11 (4), 1-16. https://doi.org/10.5539/ass.v11n4p1.

Sudarsono, Heri. 2012. Bank dan Lembaga Keuangan Syariah: Deskripsi dan Ilustrasi. Yogyakarta: Ekonisia.

Suprayitno, Eko. 2005. Ekonomi Islam: Pendekatan Ekonomi Makro Islam dan Konvensional. Yogyakarta: Graha Ilmu.

Tey, Yeong Sheng, Suryani Darham, Aswani Farhana Mohd. Noh, and Nurjihan Idris. 2010. "Acreage Response of Paddy in Malaysia." Agricultural Economics 56 (3), 135-40. https://doi.org/10.17221/54/2009-agricecon.

Toriquddin, Moh. 2015. "Pengelolaan Zakat Produktif di Rumah Zakat Kota Malang Perspektif Maqashid Al-Syariah Ibnu 'Asyur". ULUL ALBAB: Jurnal Studi Islam 16 (1), 62-79. https://doi.org/10.18860/ua.v16i1.2839.

Uyun, Qurratul. 2015. "Zakat, Infaq, Shadaqah, Dan Wakaf Sebagai Konfigurasi Filantropi Islam". Islamuna: Jurnal Studi Islam 2 (2): 218-234. http://tempojs2.iainmadura.ac.id/index.php/islamuna/issue/view/88.

Vincent, Jeffrey R. and Rozali Mohamed Ali. 2005. Managing Natural Wealth: Environment and Development in Malaysia. New York: Routledge. https://doi.org/10.4324/9781936331819.

Yusuf, Muhammad Yasir. 2015 Zakat Produktif, Mengubah Mustahik Menjadi Muzakki. Baitul Mal Aceh: Majalah Suara Darusssalam. Accessed from http://baitulmal.acehprov.go.id/2015/11/04/dr-m-yasir-yusuf-zakat-produktifmerubah-mustahik-menjadi-muzakki/, 15 January 2021. 